\title{
Cutaneous umbilical metastases in post-menopausal females with gynaecological malignancies
}

\author{
Jinekolojik malignitesi olan menopoz sonrası kadınlarda deriyi tutan \\ umbilikal metastazlar
}

\author{
Modupeola Omotara Samaila ${ }^{1}$, Adebiyi Gbadebo Adesiyun², Garba Dahiru Waziri' ${ }^{1}$ Korede Afolabi Koledade ${ }^{2}$, \\ Abimbola Omolara Kolawole ${ }^{2}$ \\ 'Department of Pathology and Morbid Anatomy, Ahmadu Bello University Teaching Hospital, Shika, Zaria, Nigeria \\ 2Department of Gynaecology and Obstetrics, Ahmadu Bello University Teaching Hospital, Shika, Zaria, Nigeria
}

\section{Abstract}

Gynaecological malignancies frequently metastasize to contiguous structures, internal organs and bones. Cutaneous metastasis as a primary or recurrent presentation of these malignancies is rare and only a few cases have been reported in the literature. A twenty year (1991-2010) retrospective search for umbilical metastasis from gynaecological malignancies in our departmental case records showed only four cases. Four postmenopausal females presented with painful cutaneous umbilical (Sister Joseph's) nodules. The clinical examinations of all four patients revealed well delineated nodules of varying sizes and degrees of ulceration. Other findings were matted axillary and inguinal lymph node enlargement, intra-abdominal and pelvic masses, vaginal discharge and vaginal bleeding. Incisional tissue biopsies from the nodules were processed in paraffin wax and stained with haematoxylin and eosin. Histology of the sections showed pigmented skin overlying metastatic malignant tumours consistent with adenocarcinoma from the endometrium and ovary in three cases, and squamous cell carcinoma, large cell keratinizing from the cervix uteri in the fourth case. Gynaecological cancers have a global spread and varied geographic distribution. Cervical cancer is the commonest in our setting and patients often present to hospital with advanced stage disease. Ovarian and endometrial cancers are infrequent and their diagnosis may be delayed by non- specificity of presenting clinical symptoms from other benign tumours at these sites. Although umbilical metastasis is commonly associated with gastro-intestinal malignancies, its presence may be the first harbinger of occult gynaecologic cancer.

(J Turkish-German Gynecol Assoc 2012; 13: 204-7)

Key words: Metastasis, umbilical, cervix uteri, squamous cell carcinoma, endometrial adenocarcinoma

Received: 04 November, 2011

Accepted: 03 January, 2012

\section{Ozet}

Jinekolojik maligniteler sıklıkla komşu yapılara, iç organlara ve kemiklere metastaz yaparlar. Bu malignitelerin primer veya rekürren prezentasyonu olarak deri metaztazlanı enderdir ve literatürde sadece bir kaç olgu bildirilmiştir. Jinekolojik malignitelerden kaynaklanan umbilikal metaztazlar için departmanımızın olgu kayıtlarında yirmi yllık (1991-2010) retrospektif taramada sadece dört olgu bulundu. Menopoz sonrası dört kadın deriyi tutan ağrılı umbilikal nodüllerle (Rahibe Joseph) başvurmuştu. Dört hastanın klinik muayenesi farklı büyüklükte ve farklı ülserasyon derecelerinde iyi sınırlanmış nodülleri ortaya koymuştu. Diğer bulgular aksillar ve inguinal lenf nodlarında paket halinde büyüme, karın içi ve pelvik kitleler, vajinal akıntı ve vajinal kanama idi. Nodüllerden insizyonla elde edilen doku biyopsileri parafin mumunda işlenmiş ve hematoksilin-eozin ile boyanmıştı. Kesitlerin histolojisi üç olguda endometriyum ve overden köken alan adenokarsinoma ile uyumlu metastatik malign tümör ve üstünü örten pigmente deriyi, dördüncü olguda serviks uteriden köken alan keratinize büyük hücreleri-yassı hücreli karsinomayı ortaya koymuştu. Jinekolojik kanserler dünyanın her yerinde bulunur ve değişken bir coğrafi dağılım gösterir. Bölgemizde en yaygın olanı servikal kanserdir ve hastalar hastaneye sıklıkla ileri bir hastalık aşamasında gelmektedir. Over ve endometrium kanserleri daha az sıklıktadır ve tanıları bu bölgelerden köken alan diğer iyi huylu tümörlerin klinik belirtilerinin özgün olmayışı nedeniyle gecikebilir. Umbilikal metastaz yaygın olarak gastrointestinal malignitelerle birlikte görülmekle birlikte, varlığı gizli bir jinekolojik kanserin ilk habercisi olabilir.

(J Turkish-German Gynecol Assoc 2012; 13: 204-7)

Anahtar kelimeler: Metastaz, umbilikal, serviks uteri, yassı hücreli karsinoma, endometriyal adenokarsinoma

Geliş Tarihi: 04 Kasım 2011

Kabul Tarihi: 03 Ocak 2012

\section{Introduction}

There is a recognized global rise in the incidence of gynaecological malignancies, although the frequency of occurrence varies in different geographic regions and these cancers have a predilection for middle-aged to elderly females $(1,2)$. The commonest in developing countries is carcinoma of the cervix uteri, which remains a major cause of cancer related death in spite of the tremendous improvements in prevention, early detection and treatment modalities (3). Cancer of the ovary is the second most frequent, however, its diagnosis is often delayed due to the absence of specific clinical symptoms to differentiate it from benign ovarian lesions. The endometrial cancers are less frequent and have a predilection for elderly females $(1,2)$. These gynaecological cancers are associated with high mortality and morbidity in our setting due to the 
patients' late hospital presentation with widespread metastases to contiguous structures intra-abdominally. Cutaneous metastases from mainly ovarian cancers have been reported in a few cases, however, umbilical metastasis from gynaecological cancers is uncommon (4-7). We report four post-menopausal females with umbilical (Sister Joseph's nodule) metastatic nodules from gynaecological malignancies in our hospital. The incision tissue biopsies from the umbilical nodules, cervix uteri and endometrium were fixed in $10 \%$ formalin. They were processed in paraffin wax and stained with haematoxylin and eosin and Periodic acid Schiff.

\section{Case Reports}

\section{Case 1}

A 50 year-old nulliparous female presented to our gynaecology clinic with a five month history of peri-umbilical nodular growth following an exploratory intra-abdominal surgery at a private clinic. However, there was no clinical diagnosis made or tissue specimen sent for histopathological analysis following the surgery. She first noticed the umbilical nodule a month after surgery. The nodule gradually increased in size and was associated with pain and weight loss. Her clinical examination revealed an emaciated woman with a $5 \times 4 \mathrm{~cm}$ umbilical nodule, a pelvic mass, a matted right axillary and bilateral inguinal lymph node enlargement. The incisional tissue biopsy taken from the nodule showed keratinized stratified squamous epithelium overlying a malignant tumour. The tumour cells were composed of columnar endometrial cells arranged in glands and focal papillary array in a fibromyxoid stroma. It was diagnosed as metastatic endometrial adenocarcinoma (Figure 1, 2).

\section{Case 2}

A 65 year-old post menopausal housewife presented to the gynaecology clinic of our hospital with a three month history of fungating umbilical growth and progressive weight loss. She gave a medical history of five years of painless abdominal mass which gradually increased in size and a two month history of discharging umbilical sinus. There was no history of associated vagina bleeding or discharge, change in bowel habit or urinary symptoms. She was referred from a private clinic with a clinical diagnosis of ovarian cancer, however she decided to try traditional medication for a month before she finally came to our hospital. Clinical examination at the gynaecology clinic showed a wasted woman having a foul smelling ulcerated umbilical nodule and a non tender mobile right supra-pubic mass which was comparable with a 16-week size uterine gestation. The uterus and cervix were grossly normal and the pouch of Douglas was empty. She also had an abdominal-pelvic scan which showed a complex ovarian mass. Incisional tissue specimen from the umbilical nodule was sent for histopathological diagnosis. It showed pigmented skin overlying a malignant tumour composed of columnar cells having moderately pleomorphic hyperchromatic nuclei and moderate cytoplasm. The tumour cells were arranged in papillary and cystically dilated glandular patterns. It was diagnosed as metastatic ovarian papillary cystadenocarcinoma. However, she refused surgery and opted for more traditional medication at home.

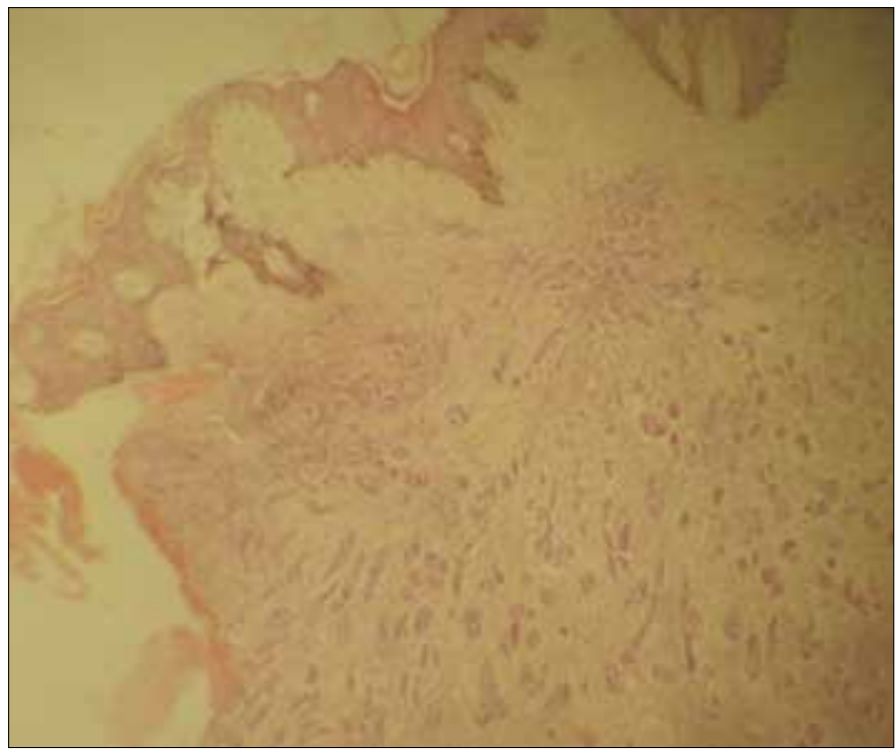

Figure 1. Keratinized Skin overlying gland forming tumour from the endometrium H\&E: mgX40

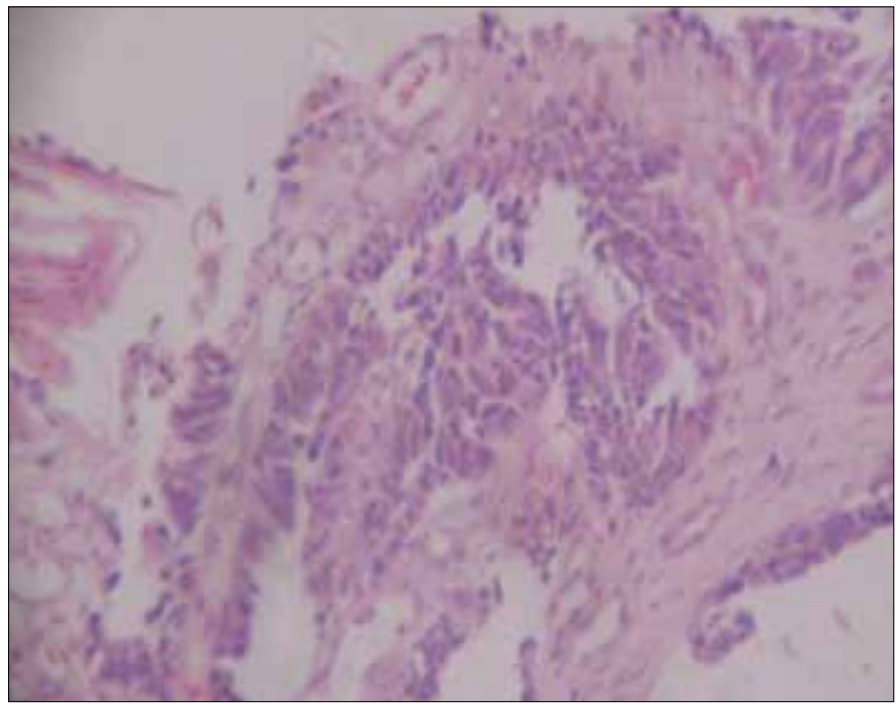

Figure 2. Metastatic endometrial adenocarcinoma with papillary foci. H\&E: mg X100

\section{Case 3}

A 70 year-old elderly grand multi-parous female presented with a six-month history of ulcerated umbilical nodule, vaginal bleeding and vagina discharge. Her examination revealed a $6 \times 4 \mathrm{~cm}$ bleeding peri-umbilical nodule and a fungating uterine cervix mass which bled spontaneously. Histopathological findings from the incisonal tissue biopsies of the nodule and the cervical mass were similar. They showed malignant squamous cells arranged in nests and strands in a fibromyxoid stroma. Some of the tumour cells exhibited individual cell dyskeratosis and keratin formation. Other areas in the nodule showed uninvolved pigmented skin and its appendageal structures. The cervical tissue was diagnosed as squamous cell carcinoma; large cell keratinizing and the nodule was diagnosed as metastatic squamous cell carcinoma (Figure 3 ). 


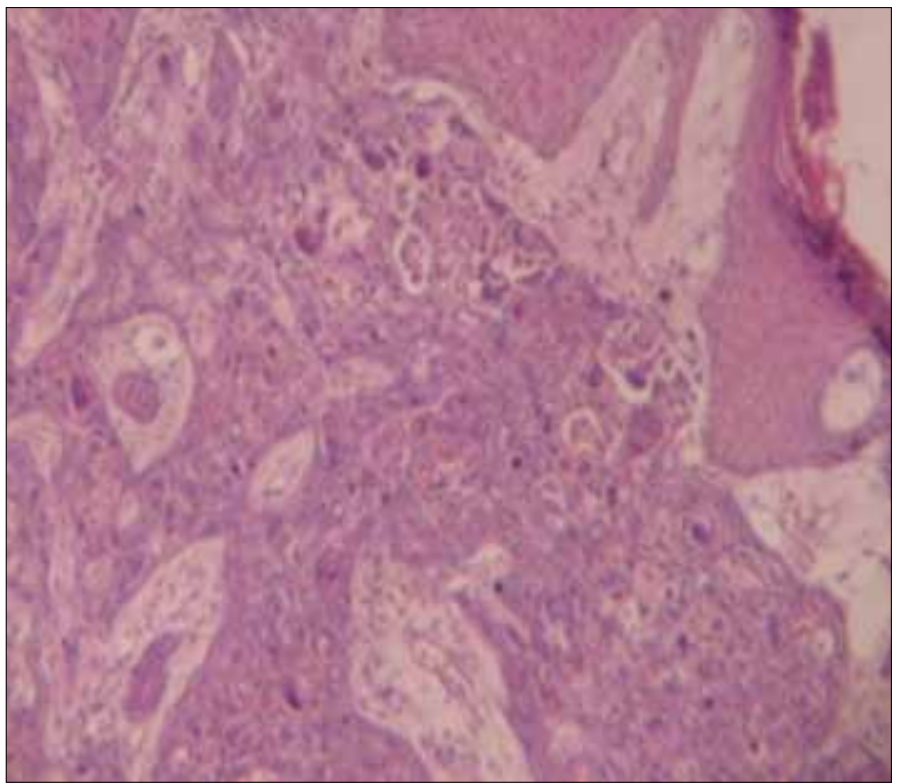

Figure 3. Metastatic Squamous cell carcinoma large cell keratinizing H\&E: mg X40

\section{Case 4}

A 72 year-old, well preserved multi-parous female presented with a three month history of painful subcutaneous peri-umbilical nodule. She was diagnosed with a histologically confirmed stage 1c endometrial carcinoma a year earlier in our hospital. She had a total abdominal hysterectomy as part of her treatment and was also placed on combination chemotherapy. Her follow up at the clinic was uneventful until this current presentation. The histopathological analysis of the incisonal tissue biopsy of the nodule showed tumour cells consistent with her primary endometrial cancer. It was diagnosed as metastatic endometrial adenocarcinoma.

\section{Discussion}

Cutaneous manifestation is associated with a wide variety of systemic diseases, infestations, and infections, while cutaneous metastasis is an uncommon event which is seen in 1-9\% of patients with cancer $(8,9)$. The phenomenon of umbilical metastasis was first noticed by Julia Dempsey (Sister Mary Joseph) in relation to advanced internal malignancies and it represents approximately $10 \%$ of cutaneous metastasis. It is an indication of poor prognostic outcome where palliation is the mainstay of patient management. Also, an estimated 1-3\% of abdomino-pelvic malignancies arising from the stomach, pancreas, colon, prostate and liver manifest with umbilical metastasis $(7,10-13)$. Other uncommon primary origins include the breast, lung, ovary and kidney.

The metastatic umbilical nodule is often painful and may be ulcerated or have discharging sinuses as seen in our patients. It should be differentiated from other lesions which may occur at the same site, such as umbilical hernia, pilonidal sinus, endometriosis, foreign body granuloma, fibroma and primary malignancies of the umbilical skin and supporting stroma. The nodule may also be the first indication of occult or recurrent malignancy. However, 11-30\% of cases of umbilical metastasis have no known primary disease $(7,13)$.

Metastatic lesions from gynaecological malignancies usually spread to contiguous pelvic structures and lymph nodes. Distant metastasis from these tumours spread to the lung, liver, bone and central nervous system (CNS) (1). Cutaneous spread is uncommon, however a few cases have occurred in the head and neck regions, particularly the scalp. Also, a rare umbilical nodule may be the first manifestation of ovarian disease $(1,6,8)$.

The exact mechanism of umbilical metastasis is not clear. There are two postulates; one is direct spread, which is the most common. This direct peritoneal spread is further enhanced by the multiple peritoneal folds comprising the umbilical ligament and ligamentum teres. The second is via the rich anastomotic vascular and lymphatic supply at the umbilical region (14).

Over $80 \%$ cases of endometrial cancer are seen in postmenopausal females at the time of diagnosis. Some microscopic variants of endometrial cancer may share similarities with nonneoplastic endometrium, while papillary foci may be mistaken for an ovarian lesion (1). Adequate tissue sampling and immuno-histochemical studies will help to differentiate the tissue of origin between the endometrium and ovary.

Cervical cancer is the commonest tumour in reproductive age women in our setting and patients present with advanced stage disease and widespread metastasis. However, our third patient is the only cervical cancer case we have seen with metastatic umbilical nodule.

The tumour types that may metastasize to the umbilicus are the adenocarcinomas, while squamous cell and undifferentiated carcinomas are rather uncommon $(5,15)$. Ovarian and endometrial cancers are gland forming and this fact may explain their tendency to metastasize to the umbilicus.

Definitive diagnosis of the tumour origin is achieved with tissue biopsy of the metastatic nodule. This is necessary for correct patient treatment and management. The fine needle aspiration cytology technique is also recommended in recurrent lesions with previous histologically confirmed diagnosis (16). However, this may prove unhelpful in our setting where patients would have visited several hospitals and had surgeries without histological diagnosis or confirmation of excised lesions.

\section{Conclusion}

Metastatic gynaecological malignancies should be a differential for postmenopausal females presenting with umbilical nodules. Adequate tissue sampling from the nodule is necessary for the typing and characterization of tumour origin as well as further patient management. Cervical squamous cell carcinoma, endometrial and ovarian adenocarcinoma may present with umbilical metastasis in the advanced stage of the diseases.

\section{Conflict of interest}

No conflict of interest was declared by the authors. 


\section{References}

1. Rosai J. Female Reproductive System-endometrium \& Ovary In: Rosai J. Ackerman's Surgical Pathology Mosby, Philadelphia, 1996; 8: 1408-531.

2. Tavassoli F.A, Devilee P. Tumours of the Endometrium In: Tavassoli F.A, Devilee P (eds) World Health Classification of Tumours. Pathology and Genetics of the Breast and Female Genital Organs. IARCPress Lyon 2003; p 221.

3. Samaila MOA, Adesiyun AG, Kolawole OA. Evaluation of cervical punch biopsy in the diagnosis of cervical cancer. Highland Medical Research Journal 2007; 5: 33-7.

4. Brustman L, Selter V. Sister Joseph's nodule. Seven cases of umbilical metastases from gynecologic malignancies. Gynecol Oncol 1984; 19: 155-62. [CrossRef]

5. Majmudar B, Wiskind AK, Croft BN, Dudley AG. The Sister (Mary) Joseph nodule. Its significance in gynecology. Gynecol Oncol 1991; 10: 152-9. [CrossRef]

6. Touraud J.P, Lentz N, Dutronc Y, Mercier E, Sagot P, Lambert D. Umbilical cutaneous metastasis (or Sister Mary Joseph's nodule) disclosing an ovarian adenocarcinoma. Gynecol Obstet Fertil 2000; 28: 719-21. [CrossRef]

7. Dubreuil A, Dompmartin A, Barjot P, Louvet S, Leroy D. Umbilical metastasis or Sister Mary Joseph's nodule. Int J Dermatol 1998; 37: 70-3.
8. Shukla P, Gupta D, Bisht SS, Pant MC. Ovarian adenocarcinoma in a young female with skin and umbilical metastasis. Indian J Med Paediatric Oncol 2009; 30: 144-6. [CrossRef]

9. Panaro F, Andorno E, Di Domenico S, Morelli N, Bottino G, Mondello R, et al. Sister Joseph's nodule in a liver transplant recipient: Case report and mini-review of literature. World Journal of Surgical Oncology 2005; 3: 4. [CrossRef]

10. Piura B, Meirovitz M, Bayme M, Shaco-Levy R. Sister Mary Joseph's nodule originating from endometrial carcinoma incidentally detected during surgery for an umbilical hernia: a case report. Arch Gynecol Obstet 2006; 274: 385-8. [CrossRef]

11. Steck WD, Helwig EB. Tumors of the umbilicus. Cancer 1965; 18: 907-11. [CrossRef]

12. Barrow MV. Metastatic tumors of the umbilicus. J Chron Dis 1966; 19: 1113-7. [CrossRef]

13. Deb P, Rai RS, Rai R, Gupta E, Chander Y. Sister Mary Joseph nodule as the presenting sign of disseminated prostate carcinoma. J Cancer Res Ther 2009; 5: 127-9. [CrossRef]

14. Powell FC, Cooper AJ, Massa MC, Goellner JR, Daniel WP. Sister Joseph's nodule: a clinical and histologic study. J Am Acad Derm 1984; 10: 610-5. [CrossRef]

15. Deng AB. Umbilical metastasis from prostate carcinoma (Sister Mary Joseph's nodule): A case report and review of literature. J Cutan Pathol 2007; 34: 581-3.

16. Schneider V, Smyczek B. Sister Mary Joseph's nodule. Diagnosis of umbilical metastases by fine needle aspiration. Acta Cytol 1990; 34: 555-8. 